\title{
Molecular Cancer Genetics in Eastern and Central Europe
}

\section{Edith Olah}

National Institute of Oncology, H-1525

Budapest 114, Pf. 21., Hungary

Over the last 10 years 25 different hereditary cancer syndromes have been identified and attributed to specific germline mutations in various inherited cancer genes. Though hereditary cancer syndromes are rare, their investigation has begun to provide unprecedented insights into the molecular origin and pathogenesis of various forms of cancer [3]. With the cloning of cancer-predisposing genes it has become possible to offer predictive DNA testing to family members at risk. For some well-defined, but uncommon inherited cancer syndromes (FAP, MEN2A, Retinoblastoma, VHL and Neurofibromatosis 1 and 2) genetic testing for cancer susceptibility is already part of the clinical management of families affected with cancer. For those inherited cancer syndromes where the risks associated with a predisposing mutation are less certain or effectiveness of preventive strategies are not confirmed, the use of genetic testing for cancer risk is not without controversies [11]. This second group includes the most common inherited cancer syndromes (such as hereditary breast cancers and hereditary non-polyposis colorectal cancers). At least five genes have been identified which may predispose to breast cancer. Germline mutations of BRCA1 and BRCA2 are thought to be responsible for the vast majority of inherited breast cancers [4].
Since the recent identification of BRCA1/BRCA2 genes [7,18], more than 600 distinct mutations in BRCA1 (and close to 600 in BRCA2) have been described (Breast Cancer Information Core (BIC) database: http://www.nhgri.nih.gov/Intramural_research/L ab_transfer/Bic/).

\section{MOLECULAR CANCER GENETIC CENTERS IN EASTERN- AND CENTRAL EUROPE}

Centers specializing in the study of inherited predisposition to cancer - particularly breast cancer - have been established in Hungary $[1,2,8,9,12]$, in Poland [6,14] and in Austria [17]. In eight other countries (Czech Republic, Latvia, Slovakia, Slovenia, Russia, Turkey, Ukraine, Yugoslavia) genetic centers are being developed, and molecular cancer genetic studies are carried out in international collaboration. (This information is from cancer centers registered by the European Association for Cancer Research.)

\section{MOLECULAR CANCER GENETIC SERVICE IN HUNGARY}

A Clinical Cancer Genetic Center has been developed at the National Institute of Oncology, Budapest as part of research projects. The patients are usually referred by oncologists, surgeons, gynecologists and radiodiagnostics, 
and are seen by a clinical cancer geneticist, oncologist and trained nurses. The family history of cancer is collected first, and verified by reviewing the clinical and histological data. The risk is calculated. The indications for BRCA testing include:

- First degree relative, age at diagnosis of breast cancer $<35$ years,

- two first degree relatives with breast cancer, mean age at diagnosis $<50$ years, or with ovarian cancer at any age,

- three close relatives with breast/ovarian cancer in two successive generations,

- one male breast cancer at any age.

It takes 3-6 months to perform standard DNA testing for BRCA1 and BRCA2 genes.

\section{BRCA1/BRCA2 MUTATION STUDIES IN CENTRAL- AND EASTERN EUROPE}

The proportion of recurrent BRCA1/BRCA2 mutations varies widely among populations (reviewed in [15]). Several mutations in BRCA1 and BRCA2 genes have been reported worldwide indicating migrations from Eastern and Central Europe, however the pattern of BRCA1/BRCA2 mutations in this region is just beginning to emerge $[1,2,5,8,9,12,13,14]$.

In order to evaluate the role of inherited BRCA1/BRCA2 mutations in Eastern and Central Europe, we are conducting an international collaborative study on patients from eight Eastern European cancer centers (Olah et al., 1999 in preparation). Until now 150 breast/ovarian cancer families were screened for mutations in the BRCA genes by combined SSCP/HD analysis, PTT and direct sequencing. Only a small number of founder mutations accounted for the vast majority of all BRCA1 mutations in each population $[2,6,8$, $10,16]$. Unlike the case of BRCA1, no such recurrent mutation patterns were observed for the BRCA2 gene. Further molecular genetic studies will help to better understand the pathogenesis of breast cancer.

\section{Acknowledgements}

This work on BRCA1/2 has been supported by research grants OTKA (T030039) and ETT (256/96) given to E. Olah, NIH FIRCA Grant (R03 TW00894-01) to M.-C. King and E. Olah, and by UICC Grants (given to C. Szabo, L. Tihomirova and L. Raicevic).

\section{References}

[1] Csokay, B., Udvarhelyi, N., Sulyok, Z., Besznyak, I., Ramus, S., Ponder, B.A.J. and Olah, E. High frequency of germ-line BRCA2 mutations among Hungarian male breast cancer patients without family history. Cancer Res. 59, (1999) 995-998.

[2] Csokay, B., Tihomirova, L., Stengrevics, A. and Olah, E. Strong founder effects in BRCA1 mutation carrier breast cancer patients from Latvia. Human Mutation 59, (1999) 92, 258 online.

[3] Fearon, E.R. Human cancer syndromes: clues to the origin and nature of cancer. Science 278, (1997) 1035-1050.

[4] Ford, D., Easton, D.F., Stratton, M., Narod, S., Goldgar, D., Devilee, P. et al. and Breast Cancer Linkage Consortium. Genetic heterogeneity and penetrance analysis of the BRCA1 and BRCA2 genes in breast cancer families. Am. J. Human Genet. 62, (1998) 676-689.

[5] Gayther, S.A., Harrington, P., Russel, P., Kharkevich, G., Garkavtseva, R.F. and Ponder, B.A.J. Frequently occurring germ-line mutations of the BRCA1 gene in ovarian cancer families from Russia. Am. J. Human Genet. 60, (1997) 1239-1242.

[6] van der Looij, M., Wysocka, B., Brozek, I., Limon, J. and Olah, E. Founder BRCA1 mutations and two novel germline BRCA2 mutations in breast and/or ovarian cancer families from North-Eastern Poland. Intl. J. Human Mutation (1999) (submitted for publication).

[7] Miki, Y., Swensen, J., Shattuck-Eidens, D., Futreal, P.A., Harshman, K., Tavtigian, S., Liu, Q., Cochran, C., Bennett, L.M., Ding, W., Bell, R., Rosenthal, J., Hussey, C., Tran, T., McClure, M., Frye, C., Hattier, T., Phleps, R., HaugenStrano, A., Katcher, H., Yakumo, K., Gholami, 
Z., Shaffer, D., Stone, S., Bayer, S., Wray, C., Bogden, R., Dayananth, P., Ward, J., Tonin, P., Narod, S., Bristow, P.K., Norris, F.H., Helvering, L., Morrison, P., Rosteck, P., Lai, M., Barrett, J.C., Lewis, C., Neuhausen, S., Cannon-Albright, L., Goldgar, D., Wiseman, R., Kamb, A. and Skolnick, M.H. A strong candidate for the breast and ovarian cancer susceptibility gene BRCA1. Science 266, (1994) 66-71.

[8] Olah, E., Csokay, B., Jarai-Kote, Z., van der Looij, M., Papp, J. and Sztan, M. Inherited BRCA1 mutations in Hungarian breast/ovarian cancer families. Magyar Onkologia 41, (1997) 69-73.

[9] Olah, E., Nemeth, G. and Papp, J. BRCA1 and other chromosome 17 genes in pathogenesis of multiple primary cancers. Proc. Am. Assoc. Cancer Res. 38, (1997) 168.

[10] Papp, J., Raicevic, L., Radulovic, S. and Olah, E. Prevalence of BRCA1 and BRCA2 mutations in Yugoslavian breast and breast/ovarian cancer families. Int. J. Oncology (1999) (in press).

[11] Ponder, B.A.J. Genetic testing for cancer risk. Science 278, (1997) 1050-1054.

[12] Ramus, S.J., Kote-Jarai, Z., van der Looij, M., Gayther, S.A., Csokay, B., Ponder, B.A.J. and Olah, E. Analysis of BRCA1 and BRCA2 mutations in Hungarian families with breast and breast-ovarian cancers. Am. J. Human Genet. 60, (1997) 1242-1246.

[13] Ramus, S.J., Friedman, L.S., Gayther, S.A., Ponder, B.A.J., Bobrow, L., van der Looij, M., Papp, J. and Olah, E. A breast/ovarian cancer patient with germline mutations in both BRCA1 and BRCA2. Nature Genet. 15, (1997) 14-15.

[14] Sobczak, K., Kozlowska, P., Napierala, M., Czarny, J., Wozniak, M., Kapuscinska, M.,
Losko, M., Koziczak, M. et al. Novel BRCA1 mutations and more frequent intron-20 alteration found among 236 women from Western Poland. Oncogene 15, (1997) 1773-1779.

[15] Szabo, C.I. and King M.-C. Population genetics of BRCA1 and BRCA2. Am. J. Human Genet. 60, (1997) 1013-1020.

[16] Szabo, C.I., van der Looij, M., Papp, J., Besznyak, I., King, M.-C. and Olah, E. Prevalence of BRCA1 and BRCA2 mutations in a Hungarian hospital-based series of incident breast and ovarian cancer cases. Proc. Am. Assoc. Cancer Res. 39, (1998) 475.

[17] Wagner, T.M.U., Möslinger, R.A., Muhr, D., Langbauer, G., Hirtenlehner, K., Concin, H., Doeller, W., Haid, A., Lang, A.H., Mayer, P., Ropp, E., Kubista, E., Amirimani, B., Helbich, T., Becherer, A., Scheiner, O., Breteneder, H., Borg, A., Devilee, P., Oefner, P. and Zielinski, C. BRCA1-related breast cancer in Austrian breast and ovarian cancer families: specific BRCA1 mutations and pathological characteristics. Int. J. Cancer 77, (1998) 354-360.

[18] Wooster, R., Bignell, G., Lancaster, J., Swift, S., Seal, S., Mangion, J., Collins, N., Gregory, S., Gumbs, C., Micklem, G., Barfoot, R., Hamoudi, R., Patel, S., Rice, C., Biggs, P., Hashim, Y., Smith, A., Connor, F., Arason, A., Gudmundsson, J., Ficenec, D., Kelsell, D., Ford, D., Tonin, P., Bishop, D.T., Spurr, N.K., Ponder, B.A.J., Eeles, R., Peto, J., Devilee, P., Cornelisse, C., Lynch, H., Narod, S., Lenoir, G., Egilsson, V., Barkardottir, R.B., Easton, D.F., Bentley, D.R., Futreal, P.A., Ashworth, A. and Stratton, M.R. Identification of the breast cancer susceptibility gene BRCA2. Nature 378, (1995) 789-792. 


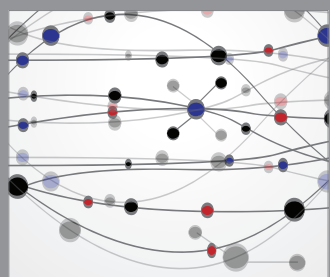

The Scientific World Journal
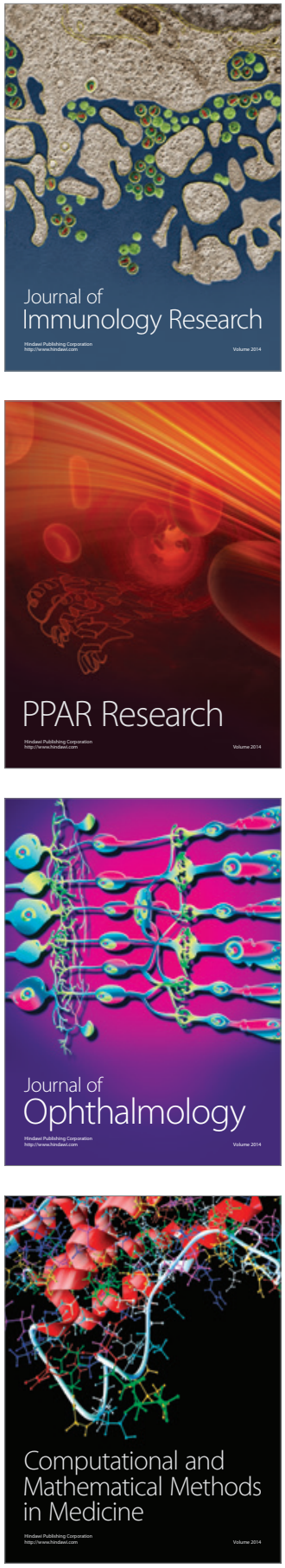

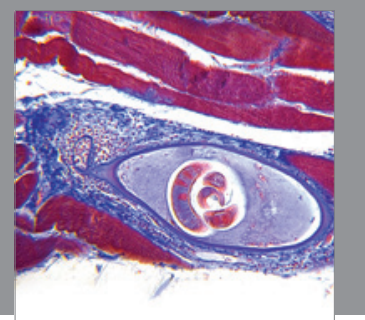

Gastroenterology

Research and Practice
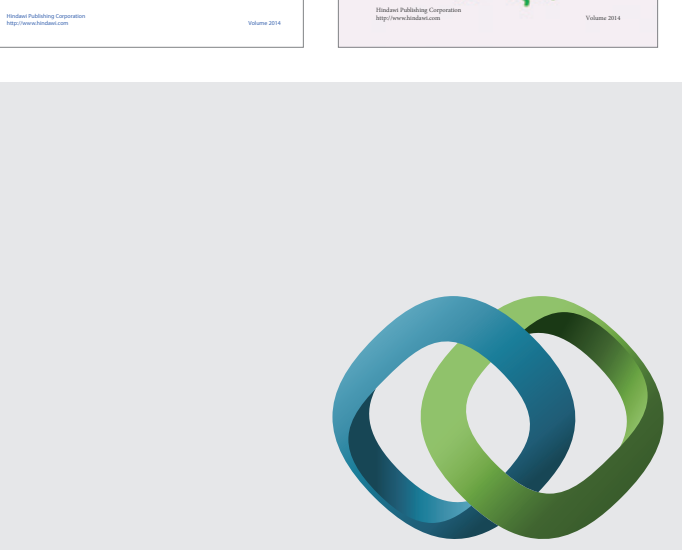

\section{Hindawi}

Submit your manuscripts at

http://www.hindawi.com
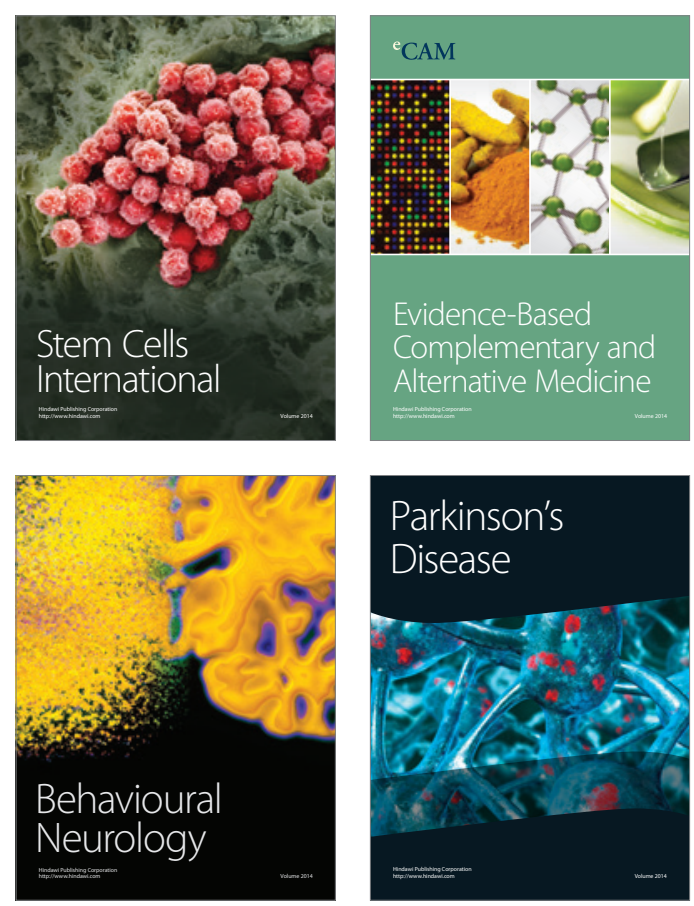

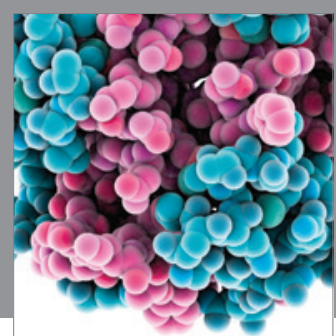

Journal of
Diabetes Research

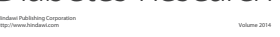

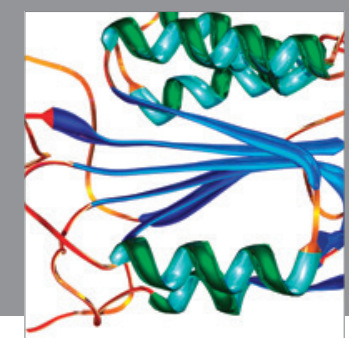

Disease Markers
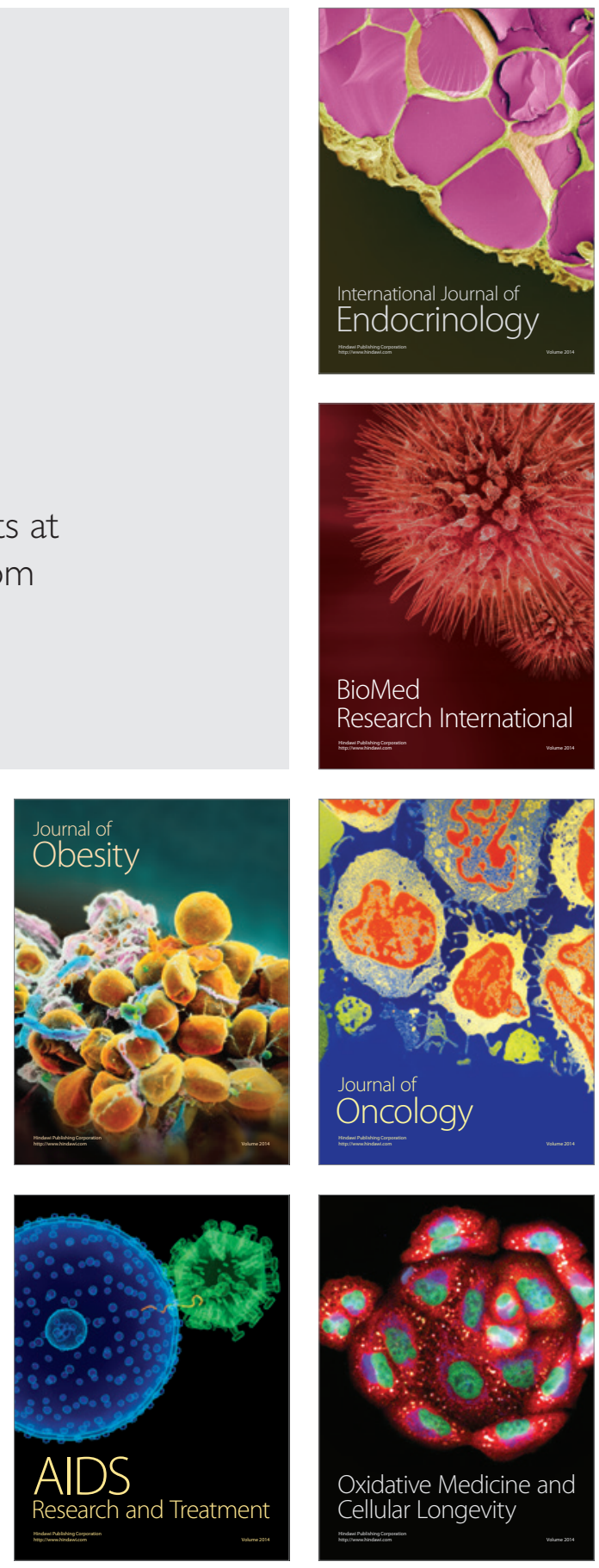